\title{
Evaluation of Pumping HR (Human Resources) Model-Based Training Program on Human Resources Development at Bogor Agricultural University (IPB)
}

\author{
Amir Tengku Ramly \\ Universitas Ibn Khaldun Bogor \\ Amir.tengkuramly@uika-bogor.ac.id
}

\begin{abstract}
The evaluation study of pumping HR model-based HRD training program at Institut Pertanian Bogor (IPB) is a program evaluation to see the program effectiveness against the professionalism and performance of employees.This research is evaluative research with a model frame of CIPP of Stufflebeam, with evaluation components: context, input, process, and product. Pumping HR model-based HRD training program at IPB is a beneficial program for employment and personal, which have an impact on performance. Considering the context, this program supports the goal of Human Resource Development of IPB. Considering the input, this program is designed tailored to the need of Human Resource in IPB to (1) reinforcement of the values and beliefs, (2) strengthen competence, and (3) encourage successful behaviour in terms of responsibility, professionalism and friendliness in working. Considering the process, this program is preferred and fun for participants and considering the product (output and outcome) this program provides benefits and clear impacts for the performance of the employee.
\end{abstract}

Article Info

- Received : March 07, 2019

- Revised : May 19, 2019

- Published : June 18, 2019

- No. Pages : 153-163

- DOI : 10.33019/ijbe.v3i2.154

- JEL : M53, O15

- Keywords : program evaluation, human resource development, pumping hr model, training based pumping hr, human capital

\section{Introduction}

To enhance the professionalism and performance of the employees, IPB by the Human Resource Directorate did the learning process towards educational personnel, for example through a training program. IPB (2012) mentioned that individual/clerk behaviour in IPB can determine his success in working that is in the form of achievement or performance that is the basis to distinguish employees with superior and average performers. HRD training program is very important for IPB since Human Resource is a strategic asset for the organization of IPB (IPB, 2013). According to Noe, et.al (2010) strategic assets are largely determined by the role of the organization in preparing evidence-based Human Resource (Evidence-Based HR) which is able to compete strategically through practices of competitiveness $M S D M$. In order to offer a competitive advantage, training 
should involve a wide range of human needs, more than just skill improvement (hard skill), but also behaviour, character and knowledge as well as other soft skill competencies. Human capital itself according to Baron and Armstrong (2007) is an intangible asset of the organization. Human capital is the intangible resource given by the employee to the organization. The paradigm of human capital put man as the main foundation in supporting the success of the organization in the future (Agung, 2007).

Pumping HR model-based HRD training is the training of human capital that is an intangible asset. The training is based on the development of personality, competencies and values of human spirituality. According to Hadiyat and Poniman (2015), the concept of competitive advantage is fundamentally shift the strategy focus from the tangible assets to intangible assets. The strategy of strengthening tangible assets such as factories and machinery will answer the comparative advantage but the competitive advantage of an enterprise for global competitiveness will be obtained through strengthening the strategy of intangible assets of knowledge, information and technology.

Results of the survey on the practice of talent (personality) management, Berger and Berger (2007) concluded: "to optimize the ability in achieving a lasting advantage, organizations must have proactive talent management and have a systematic way to do the talent management activities". Understanding, strengthening, and talent management is becoming increasingly important for organizations that are oriented on the needs of the customer, service and competitive power. The importance of the competence factor in Human Resource development has emerged since 1973 through the work of Prof. David McClelland entitled "Testing for Competence Rather than Intelligence", which was later known as the CBHRM (competency-based human resource management). While the importance of spiritual values in the Human Resource development is clearly stated in the view of the Zohar (2001), spiritual values are the foundation for spiritual intelligence used to make a variety of goodness, truth, beauty, and compassion in our lives. SQ is something we use to develop the ability and yearning for meaning, vision, and values. According to Yusuf (2006), spiritual needs are the highest needs owned by a person, over the five basic human needs that are popularized by Abraham Maslow.

Training program evaluation in IPB is an important part of addressing the issue of individual capacity development of educational personnel's employee (tendik) in IPB. It is still a major concern of the Directorate of the Human Resource of IPB, since considering the strata of education of the educational personnel is still dominated by High School graduates (54\%) and the rest are graduates of the Elementary School, Junior High School, Diploma, S1, and S2. In addition to the low education, the educational personnel's in IPB also occupy the positions that are still low, i.e. still dominate the II/a and III/b. It is worrying that it will affect the performance of the educational personnel within the long term. Performance of the educational personnel's in IPB is considered based on four main criteria: (1) presence, (2) productivity, (3) working behaviour and (4) the assessment of the working unit/related agencies.

The focus of this research was to look at the effectiveness of the pumping HR model-based individual development training program of HR of IPB which in this case was limited to the $K T U$, kasi and kasubdit who have ever attended the training program. The sub-focus of the research are: (1) the purpose of the training program toward individual behaviour change, (2) design of training programmes based on learning objectives input (3) the implementation of the training program 
that was focused on the learning experience gained by participants, (4) the result (output) of the training program that was focused on individual capacity development of the training program alumni, and (5) impact (outcome) of training program that was focused on the individual change post-training.

\section{Literature Reviews}

The framework of Pumping HR model is formed in three major foundations, namely; pumping principle, pumping competency and pumping action sourced from existing theoretical approaches and tested scientifically, that (1) uses the parable of the good tree which consists of root, stem and fruit/leaves, (2) rests on the principles of the model of the milky way (the solar system) consisting of the centre point of the orbit, the orbit and the orbital line, (3) rests on the theory of the Iceberg that shows three human nature, namely subconscious (unconscious), pre-conscious and conscious, (4) rely on modern theories about the gift of humanity, that is, sensory perception, brain, and heart.
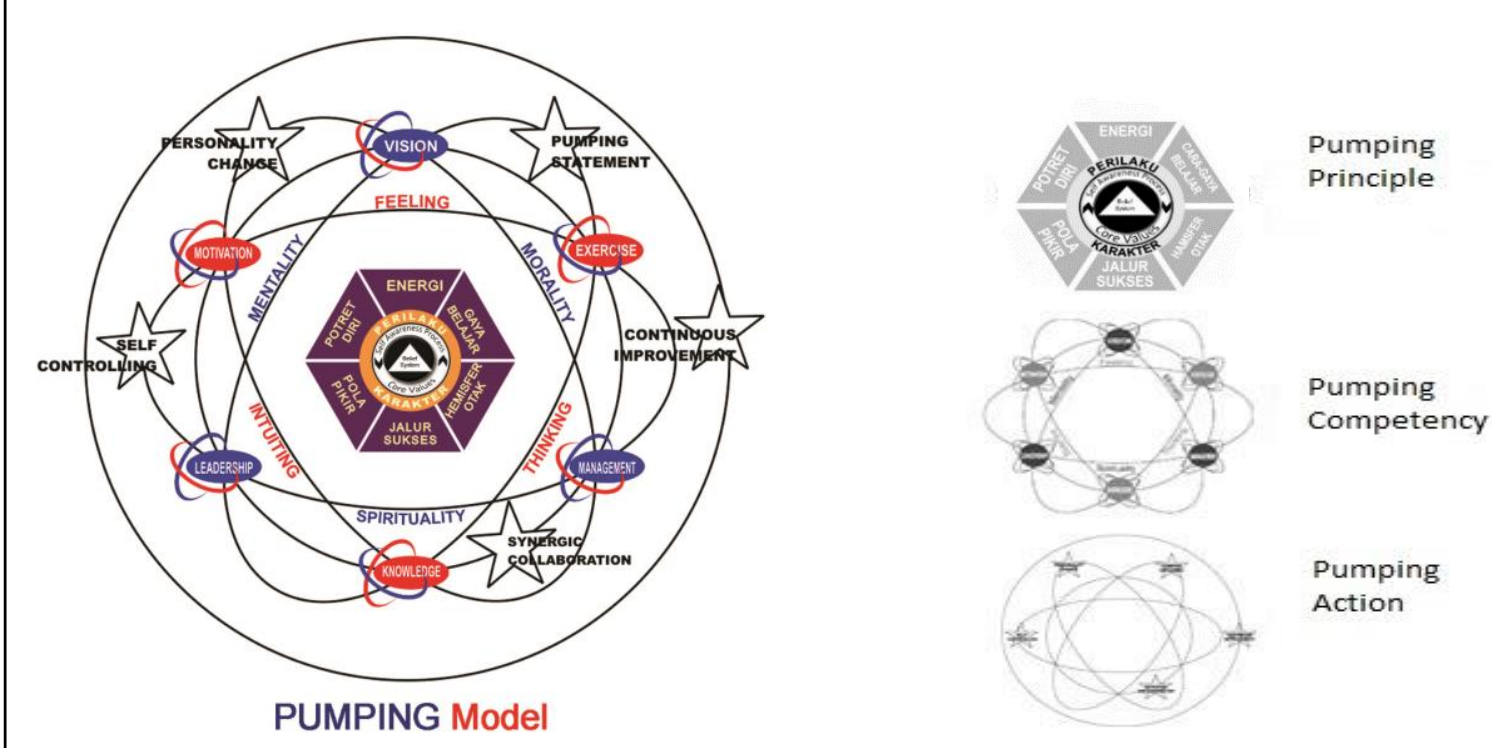

Figure 1. The Learning Concept of Pumping HR model Approach

Considering the concept, Pumping HR model refers to the theories of talent management and competency management of experts such as David McClelland, Michael Armstrong, Gary S Becker, Angela Barron, Dave Ulrich, R Palan, Lance A Berger, Dorothy R Berger, Michael Zwell, and others. Pumping HR model uses the concept of human capital, where it combines the potential of talent, behaviour, personal ability, professional ability, the competence of intangible and spiritual intelligence (SQ), emotional intelligence (EQ), as well as adversity quotient (AQ). Pumping HR model as the concept of human capital emphasizes on the importance of the development of the human element through the strengthening of value, belief system, selfawareness process and exploring best potentialities as behaviour and character lead to the selfsuccess and profession.

Evaluation is the process of describing, acquiring, and providing descriptive information that can be used to decide about the value and benefits of some objectives, design, implementation, and influence in decision-making, serving the need for accountability and improving understanding of 
the phenomena involved. According to Djaali and Mulyono (2008) evaluation can be defined as the process of judging something based on criteria or objectives that have been set as well, which then followed by the decision making over objects that have been evaluated. This definition is completed by Stufflebeam and Coryn (2014) by stating "we have characterized the work of evaluation in four tasks: delineating, obtaining, reporting, and applying".

Whereas the program evaluation is a systematic method to collect, analyse, and put the information to answer basic questions about the program. According to Wirawan (2012), program evaluations can be grouped into the process evaluation, the outcome evaluation and the impact evaluation. The process evaluation is the evaluation to examine and assess whether the program service has been implemented as planned. This evaluation also assesses the implementation strategy of the program. The outcome evaluation is an evaluation that assesses and define whether the program has obtained the expected changes. While the impact evaluation is an evaluation that assesses the extent the program provides the impact or influence on the organization's main objectives, namely an increase in the employee's performance.

Detty, et al (1999) states that there are several reasons why training evaluation is needed, namely: (1) training program evaluation can provide a diagnostic to the company about the form of the revision that should be done to the training program that has been running in order to be able to achieve the objectives, (2) training program evaluation can provide a beneficial legal implication, and (3) training program evaluation will affect the decision to determine an alternative program and participants that will be prepared for the future. Kirkpatrick (2009) argues that there are at least four important levels that should be in the training program evaluation, namely (1) reaction, (2) learning, (3) behaviour, and (4) results. While according to Stufflebeam (2014) an evaluation of a program can be done through the CIPP model consisting of four types of evaluation, namely context evaluation, input evaluation, process evaluation, and product evaluation.

\section{Research Methods}

This research used evaluation methods, qualitative approach, supported by statistical data as a scientific method to analyse existing data intended to see the effectiveness of HR development training program in IPB. The selected evaluation model was a model of the CIPP of Stufflebeam, with four components of evaluation, namely: context, input, process, and product. The data was collected through the study of documents, interviews and observations, which were classified as primary and secondary data. Analysis of qualitative data was conducted through stages of data reduction, the presentation of the data and the withdrawal of the conclusion. Quantitative data were processed using simple statistics and weight values and percentages.

CIPP model was chosen as some of the main reasons, namely (1) CIPP model is a dynamic system of evaluation work, (2) has a holistic approach in its evaluation process which aims to provide a detailed and extensive description of a project, from the context of the implementation process, (3) can perform improvement during the running programs, can also provide final information useful for the decision making (4) has the potential to move at a formative and summative evaluation, (5) or more comprehensive from other evaluation models.

\section{Results}


Pumping HR model-based HRD training program in IPB is an effective training program and benefits for participants. The program provides benefit and impact that was good for the improvement of the capacity and performance of its alumni. This program was fun for program alumni and remains remembering after 4-7 years passed. According to experts and practitioners of Human Resources 'fun' and 'remember' show that the program has a uniqueness that created a certain impression. Remember leads to joy and readiness to practice in daily work. The results of the questionnaire illustrate $77 \%$ of participants stated that the training was fun, as seen on Table 1.

\section{Table 1. Pumping HR model-Based HRD Training Program in IPB in the view of Alumni of the Training in 2008 to 2011}

\begin{tabular}{lc}
\hline \multicolumn{1}{c}{ Condition/View of Alumni } & Percentage (\%) \\
\hline Fun & 77.0 \\
In accordance with the objectives of participants and & 78.5 \\
institutions & 78.5 \\
Beneficial &
\end{tabular}

Results of interviews with experts and practitioners of Human Resources argue that fun training will positively impact on employee productivity. According to the practitioners, $77 \%$ describe working with the passion of the participants. Anything done in accordance to the passion will give positive results. Pleasure in working will affect productivity and positive results, not only for the work but also for the self-employees and work environments. Fun is part of the affecting memory and a good impression on the related program. This is influenced by the material and the trainer. Fun means the material being presented and the people who present are nice and fun.

This program has provided a great influence on the three important objectives of the pumping HR model-based HRD training program, namely: (1) the conviction of the participants to achieve success (pumping principle) through their current profession or position, (2) the strengthening of competencies to achieve success (pumping competency) through professional behaviour that is in accordance with working culture in IPB, and (3) the urge to perform successful actions (pumping action) in working and everyday social relations. Based on the results of the questionnaire of the training program influences the three important objectives mentioned above is as shown in Figure 2 below.

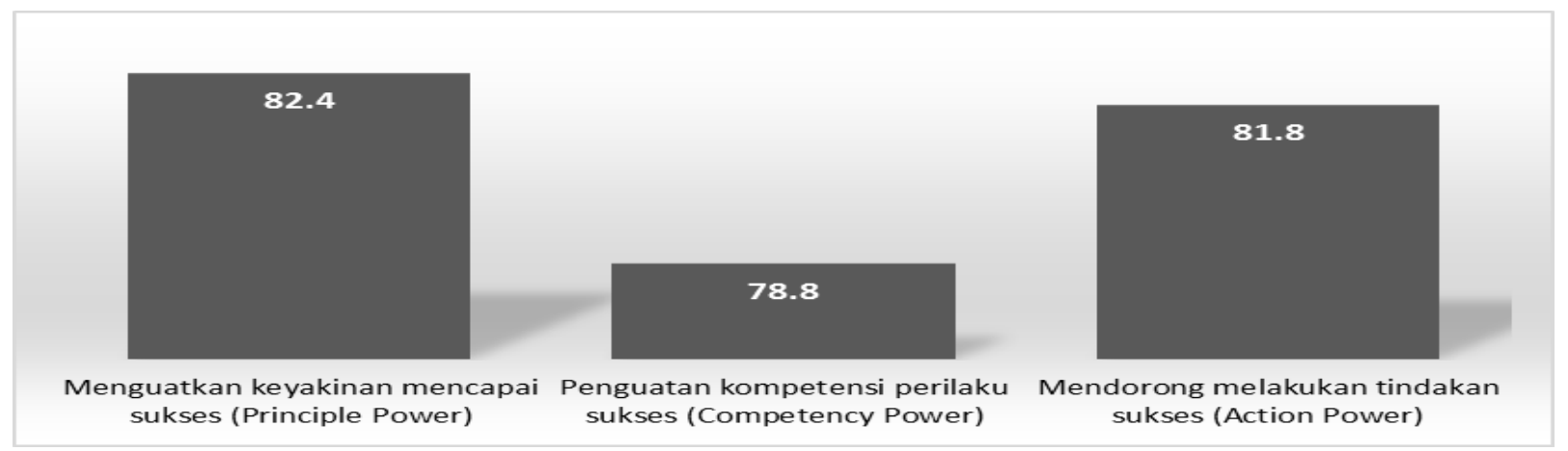

Figure 2. Percentage of HRD Training Program Influence towards the Achievement of Training Objectives in the Structure of Pumping HR model 
According to experts and practitioners of Human Resources, the structure of the pumping HR model is very attractive with the analogy of roots, stems and fruits. The tree will not look perfect if the stems are good, roots are powerfully, but are not fruitful. Belief is the foundation of human beings to be successful. Pumping HR model-based HRD training program in IPB is designed to strengthen three key components to success, namely (1) the Principle through the strengthening of confidence and values of IPB working culture, (2) Competency through strengthening motivation, working behaviour and professionalism in working, and (3) the Action through empowerment of sensory perception (physical) to be active, friendly and serve with a smile and sincere behaviour.

\section{Context Evaluation: Training Program Objectives}

Context evaluation in this research by assessing the results of the component evaluation of the goal of pumping HR model-based HRD training program in IPB, is indicated by three aspects, namely (1) the formulation of the program objectives (2) the basic of the formulation, and (3) the target of the achievement. Evaluation results of the component of the goal evaluation have been in accordance with the context of the CIPP model. The objective formulation of the training program was in accordance with the criteria i.e. conformity with the outline of the goals and needs of the participants as well as guidelines for the management of HR of IPB. The base of the program objectives has a correlation with the HRD objectives in the strategic plans of the IPB.

In the goal achievement, there is a link between the goal achievements of the individual development with indicators of HR development of IPB. The basic/foundation of the training program was implemented based on the strategic plan for HR of IPB and the HR development guidelines written in the training program proposals. The base of the training program objective was a proposal that has been drawn up and approved by the HR of IPB and the training needs analysis presented by the director, the Head of Division, and Head of Training Division. In the strategic plan of HR of the IPB, one of the strategies was to develop the professionalism of educational personnel through the achievement of the professionalism competence improvement in the perspective of world-class universities.

\section{Input Evaluation: Training Program Design}

The input evaluation assessed the design of pumping HR model-based HRD training program in IPB related to the following aspects: (1) learning goals, (2) criteria of participants, (3) criteria of the trainer team, (4) the training syllabus, (5) training methods, (6) learning approach, and (7) training location. There were learning goals, criteria of participants, criteria of the trainer team, the use of training methods, learning approach used and clear training location and in accordance with the indicators in the CIPP model in the evaluation results of this training program.

From the input evaluation results of the program design whether through interviews, document studies and observations, it is found that pumping HR model-based HRD training program design in IPB has already met the existing standards, whether the standard of the training participants, trainer team, training approaches, the determination of the material used, method design and the study treatment design. Standards of educational personnel are as the trainee is people have positions that require self-development as well as competence in their work defined by the Directorate of HR of IPB after having coordination with another directorate, faculty, departments and related units.

\section{Process Evaluation: Training Program Implementation}


Process evaluation assessed the component effectiveness of the training program implementation of the pumping HR model-based HRD training program in IPB which is indicated by the aspects of (1) use of a rundown of events, (2) use of learning contracts, (3) ice breaker (3), training techniques, (5) self-assessment test, (6) the process of material delivery, (7) the process of pumping principle, (8) the process of pumping competency, (9) the process of pumping action, and (10) the training program supervisory.

The results obtained from the interviews, the document studies and observations in the training program implementation has already been provided on a clear event rundown, contract learning and event agenda with a clear time duration. At the beginning of the session, the team trainer also did a reading of the learning contracts and icebreaker to make the class atmosphere fresh and get to know each other. In addition, training techniques which were presented were very enjoyable with the two-way communication technique that was live and fun. Participants were given the results or reports of the assessment test on the second day which then the discussion and simulations were conducted to understand the behaviour and characters in working.

The process of the material delivery was also in compliance with the evaluation criteria of the CIPP model. The material delivery was reinforced with the learning media in accordance with the needs such as LCD and screen, theatre standard sound system, simulation tools and forms support the material that is being presented. In general, components of the process evaluation of all aspects have been in accordance with the criteria of the process evaluation of the CIPP model.

The evaluation results of the end of training, participants argued that this training program was very educative because it could empower cerebral, and very touching because it has a way of empowering the heart, and very enjoyable due to the physical activities. Some impressions of the participants toward this training program were: (1) The best programme, (2) The program is very good as a means of self-development, (3) The program is very rewarding and educative, (4) The program is very useful for steadiness in spending life, (5) This program increases the motivation to work, and (6) This program gives confidence in the work being done and increases confidence.

\section{Product Evaluation: Output and Outcome of the Training Program}

Product evaluation of the pumping HR model-based HRD training program in IPB in terms of two major things, namely (1) results (output) of the training program, and (2) impact (outcome) of the training program. Output evaluation assessed the program effectiveness through product components of the training program that is indicated by the aspects of (1) benefits of post-programs and (2) improvement of the individual capacity. Outcome evaluation assessed the effectiveness of the program through the product component of the training program that is indicated by the aspects of (1) the impact of the program on alumni and their work, and (2) the program impact on the performance of the training program alumni.

\section{Program Output}

A change in attitude and behaviour in working on pumping HR model-based HRD training program in IPB is an aspect that can be perceived by participants after the training. The indicators used in the evaluation of this aspect of the product component of CIPP were the achievement success to the attitude and behaviour change in everyday activities and employment of the training program participants. Alumni of the training program were seen in everyday life are more friendly, smile and happy to say hello when they meet. These are good attitudes in accordance with the guidelines for the development of HR in IPB in strengthening individual behaviour competence. 
The pumping HR model-based training program emphasizes the action power through an attitude and behaviour change of the participants in facing daily work, friends or customers.

The questionnaire results of the $78.8 \%$ of participants stated that the pumping HR model-based HRD training program in IPB was beneficial. Its detail usefulness is as shown in Figure 3 below.

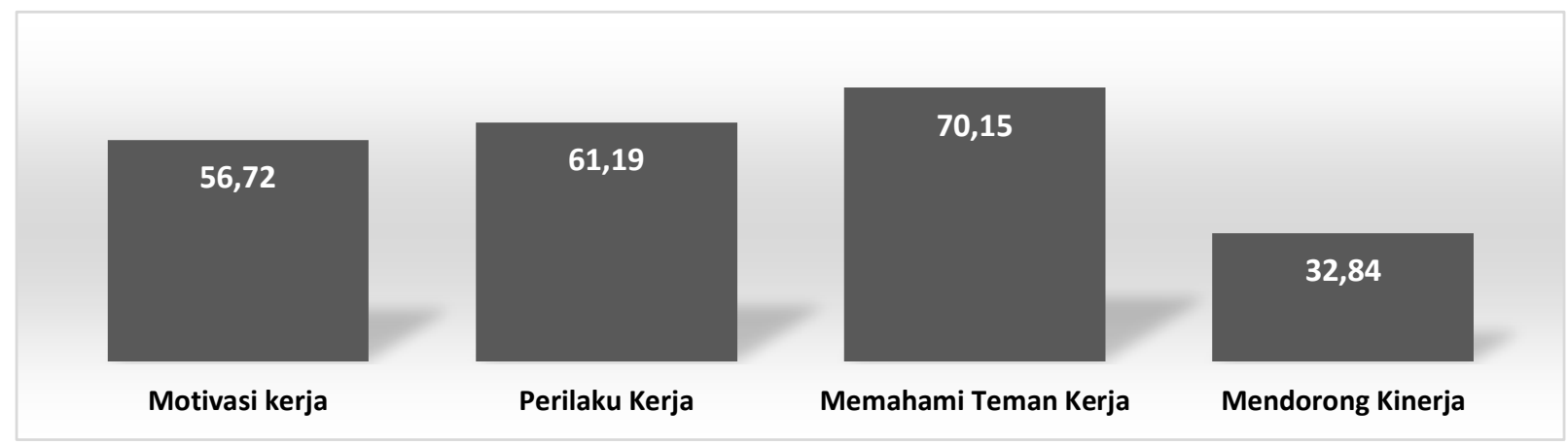

\section{Figure 3. Benefits percentage of the Pumping HR model-Based HRD in Improving Capacity of the individual participants}

The evaluation results indicated that the training program has been giving output in addition to the perceived benefits also changed attitudes and behaviours of the participants, such as: (1) better appreciate other people, (2) understand more about nature/character of a person, person in a lower or upper position (3) be positive, (4) be able to control emotions, (5) avoid the debate, (6) focus on win-win solution in solving problems, (7) be firmly in acting, (8) know how to release the working pressure (9) be able to build a better social behaviour. The increase of competence in working was one of the important aspects of the three objective aspects of the pumping HR modelbased HRD training program in IPB. The increase of competence in working on this program was strengthening behaviour, mental attitude and individual values and participants' profession in working. Indicator of the success of this aspect in the product evaluation CIPP model is the achievement success of the increased competence of post-program in accordance with annual achievement of HR of IPB.

The results of the questionnaire also show that there are benefits gained by the alumni from the training program, namely (1) increasing working motivation $(56.72 \%)$, (2) building good working behaviour $(61.19 \%)$, (3) understanding friends in working place $(70.15 \%)$, and encouraging improved performance $(32.84 \%)$. The results of questionnaire also show that there are four components who feel the benefit from the training program, namely (1) individual himself $(70.15 \%)$, (2) family (31.34\%), (3) job (74.63\%) and (4) life in general (34.33\%). Other benefits perceived by alumni for strengthening attitudes and behaviour are: (1) be able to solve problems through the win-win solution concept, (2) be more capable in directing subordinates, (3) be wiser in taking decisions, (3) be clear in acting, (4) be able to understand the behaviour of subordinates and superiors, (5) work more efficiently, and (6) establish the mind-set, attitude and character of leadership in themselves.

\section{Program Outcome}

The results of interview, the study of documents and observations found the existence of the impact of the pumping HR model-based HRD training program in IPB. There are two major impacts that 
affect the effectiveness of the training program, namely (1) the impact on the alumni themselves and their work, and (2) the impact on performance.

The results of observation and interviews found that the training program alumni look nicer in their everyday life, willing to greet and smile when they meet. Related to their job, the training program alumni expressed become sincerer in working, considering their work as worship, feel in everyday life that work is an obligation that must be accounted to God. The alumni also feel that they are able to control emotions, prefer to avoid the debate, seek mutually beneficial solutions. Changes of the performance of the trainee before taking training courses and post-training programs based on the results data of the evaluation of the annual performance of the Directorate of HR of IPB is as shown in Table 2 and Table 3 below.

Table 2. The Annual Performance of the $K T U$ of IPB as the Alumni of the Pumping HR model-Based HRD Training Program

\begin{tabular}{lccc}
\hline \multirow{2}{*}{ Year } & \multicolumn{3}{c}{ Performance (\%) } \\
\cline { 2 - 4 } 2008 & Presence & Productivity & Working Behaviour \\
2009 & 91.81 & data unavailable \\
$2010^{*}$ & 87.78 & 91.69 & 91.24 \\
2011 & 90.64 & 88.81 & 87.50 \\
2012 & 91.16 & 93.37 & 90.85 \\
\hline
\end{tabular}

Source: Directorate of HR of IPB (analysed). * No training program

Table 3. Annual Performance of the Officials of Kasubdit-Kasi of IPB Alumni of the Pumping HR model-Based HRD Training Program

\begin{tabular}{ccccccc}
\hline \multirow{2}{*}{ Year } & \multicolumn{2}{c}{ Presence } & \multicolumn{2}{c}{ Productivity } & \multicolumn{2}{c}{ Working Behaviour } \\
\cline { 2 - 6 } & S-Likert & \% & S-Likert & \% & S-Likert & \% \\
\cline { 2 - 7 } 2010 & 4.19 & 83.80 & 4.45 & 88.98 & 4.50 & 90.06 \\
2011 & 4.48 & 89.56 & 4.49 & 89.87 & 4.66 & 93.21 \\
2012 & 4.73 & 94.50 & 4.73 & 94.50 & 4.73 & 94.50 \\
2013 & 4.85 & 97.00 & 5.00 & 100.00 & 5.00 & 100.00 \\
\hline
\end{tabular}

Source: Directorate of HR of IPB (analysed)

The results of the annual evaluation against the $K T U$, year 2010-2011 is that there is an increase in the performance in terms of (1) the average attendance from $87.78 \%$ to $90,64 \%,(2)$ the average productivity from $88.81 \%$ to $93,37 \%$, and (3) the average working behaviour from $87.50 \%$ to $90,85 \%$. While the results of the annual evaluation of The Head of Subdivision in 2010-2011 was an increase in the performance in terms of: (1) the average attendance from $83.80 \%$ to $89.56 \%$, (2) working productivity from $88.98 \%$ to 89.87 , and (3) the working behaviour from $90.06 \%$ to $93.21 \%$. The results of questionnaires of the alumni of the training program found $32.84 \%$ of alumni state that this program is directly influential against the improvement of their performance. 
The training program followed by participants has provided strong encouragement for them to improve their performance post-training. This indicates that the training program gives a good impact for the alumni of the training program.

From the results of this research, some things are related to the managerial implications that can be done by the HR Directorate of IPB in developing HR quality of educational personnel in IPB. It is through (1) implementing pumping HR model-based HRD training program in IPB at all faculties and units in IPB periodically 6-12 months, (2) making the pumping HR model-based HRD training as one of the training model for the Ministry of Higher Education, Research and Technology and the Ministry of the PAN in order to the development of educational personnel in colleges and other civil servants, (3) making the pumping HR model-based HRD training as one of learning approach to improve the quality of HR in the public and private universities in Indonesia, (4) making the pumping HR model-based HRD as one of the theories that are developed in the world of education, the study program of HR management as a concept and practice in HRD in Indonesia.

\section{Conclusion}

Pumping HR model-based HRD training program provides benefits for capacity development of individuals and provides a positive influence towards performance improvement of the training program alumni. The objectives of the pumping HR model-based HRD training program in IPB in accordance and synergistic with indicators of behavioural of core competencies oriented to selfdevelopment, teamwork and internalization of IPB culture contained in guidelines for the development of HR of IPB. The design of the training program was in accordance with the specified standard of resources ranging from learning objectives, criteria for participants and trainers, syllabus, method, approach and the selection of the training location. The implementation of the training program has provided a good learning experience to participants in accordance with the needs of the competency of HRD of IPB.

Results/output from the training program provides benefits for alumni of the training programs, namely in terms of (1) an understanding of teamwork, (2) increasing the working motivation, (3) strengthening the working behavioural, and (4) encouraging better performance. While the impact (outcome) of the training program provides a positive influence to increase the performance of the alumni of the related training program. The results of the research provide important contributions to the development of knowledge in particular areas, namely the MSDM becomes an alternative concept of the development of Human Resources of an employee with the base of pumping HR model with three main concern, namely the principle for success, competence and actions for success.

\section{References}

1) Agung, A.M L. (2007). Human Capital Competencies. Jakarta: ElexMedia Komputindo.

2) Baron, A \& Armstrong, M. (2007). HCM; Achieving Added Value Through People. London \& Philadelphia: Kogan Page.

3) Berger, L. A. \& Berger, D. R. (2007). The Handbook of Best Practices on Talent Management terjemahan Kumala Insiwi Suryo. Jakarta: Penerbit PPM. 
4) Djaali dan Muljono, P. (2008) Pengukuran dalam bidang Pendidikan. Jakarta: Grasindo.

5) Detty, R, et al. (2008). Evaluasi Ke-Efektifan Program Pelatihan "Know Your Customer \& Money Laundering" Di Bank X Bandung, proceedings National Conference on Management Research, Online: http://asp.trunojoyo.ac.id/ wp-content/uploads/2014/03/EVALUASI-KE-EFEKTIFANPROGRAM-PELATIHAN.. Regina-Dety-dkk.pdf (diakses 21 Januari 2016).

6) Goodman, M. (2009). ASCD Online, http://www.ascd.org/ASCD/ pdf/journals/ ed_lead/el200910_kohm_iceberg.pdf (diakses tanggal 27 November 2014).

7) Gynanjar, A. (2012) Emotional Spiritual Quotient. Jakarta: Arga.

8) IPB. (2013). Strategic Plan Bogor Agricultural University. Bogor.

9) IPB. (2012). Rencana Strategis SDM IPB Menuju Perguruan Tinggi Berbasis Riset Kelas Dunia. Bogor: Direktorat SDM IPB.

10) IPB. (2013). Pedoman Pengelolaan SDM IPB. Bogor: Direktorat SDM IPB.

11) Kirkpatrick, D. L. K. \& James D. K. (2009). Evaluating Training Programs. Third Edition. The Four Levels. San Francisco CA: Berrett-Koehler Publishers.

12) Noe, R. A., Hollenbeck, J. R., Gerhart, B. dan Wright, P. M. (2010). Manajemen Sumber Daya Manusia, Mencapai Keunggulan Bersaing terjemahan: David Wijaya. Jakarta: Salemba Empat.

13) Palan, R. (2009). Competency Management. Jakarta: PPM.

14) Poniman, F. dan Hadiyat, Y. (2015) Manajemen HR STIFIN Terobosan Mendongkrak Produktivitas. Jakarta: Gramedia.

15) Ramly, A. T. (2016). Pengembangan Sumber Daya Manusia yang Unggul Berbasis Pumping-HR Model. Jurnal Manajemen, 7(2), 138. doi:10.32832/jm-uika.v7i2.1110.

16) Stufflebeam, D. L. and Coryn, C. L. S. (2014). Evaluation Theory, Models, \& Applications. San Francisco: Jossey-Bass.

17) Wirawan. (2012). Evaluasi: Teori, Model, Standar, Aplikasi, dan Profesi. Jakarta: Rajawali Pers.

18) Yusuf, N. Q. (2006). The 7 Awareness: 7 Keasadaran Hati dan Jiwa Menuju Manusia Diatas RataRata. Jakarta: Grasindo. 